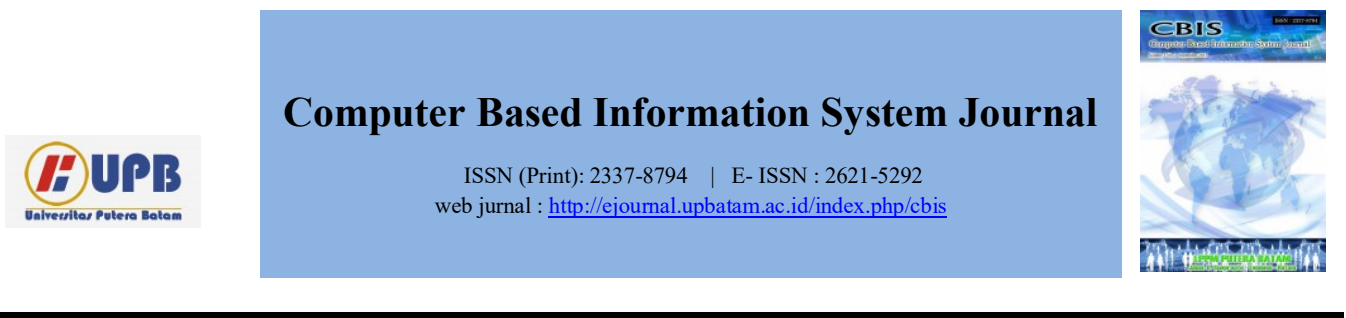

\title{
Penerapan Metode Asosiasi Dengan Algoritma FP-Growth Pada Data Transaksi PT John Tampi Group
}

\author{
Dhea Indahsari' ${ }^{1)}$, Vani Natali Christie ${ }^{2)}$, Iqbal Maulana ${ }^{3)}$ \\ 1),3) Universitas Singaperbangsa Karawang, Indonesia \\ 2) Universitas Negeri Semarang, Indonesia
}

\section{INFORMASI ARTIKEL}

Diterima Redaksi: Agustus, 2021

Diterbitkan Online: September, 2021

\section{KATA KUNCI}

FP-Growth Algorithm, Data mining, Association Method, Restaurant,

Transaction

\section{KORESPONDENSI}

E-mail:

dhea.indahsari17084@student.unsika.ac.id

\begin{abstract}
A $\quad$ B $\quad \mathbf{S}$ T $\mathbf{R}$ A $\mathbf{C}$ T
The development of business in the food sector over time is increasing and is always growing and will never stop. With the rapid growth of the food business, there is competition between business owners. Businesses in the food sector on average do not require large capital but in practice investors or developers need to know the sales pattern so that it can be used as a reference as an effective marketing and sales strategy in developing development at a later stage. Not only that, competition in the culinary world is getting tougher since the pandemic status was announced. This adds to the challenge in the culinary world competition to find strategies that can increase sales and marketing of products sold, including through the use of product sales data. The application of the data mining association method using the FP-Growth algorithm is used to help find an association rule from product sales data at PT John Tampi Group. From the results of the tests carried out, the rules with the best Confidence value reached $100 \%$.
\end{abstract}

\section{Latar Belakang}

Perkembangan dunia usaha di bidang restoran terjadi sangat cepat. Hal ini ditandai dengan munculnya banyak restoran dengan berbagai karakteristik atau konsep yang berbeda. Dengan pesatnya pertumbuhan bisnis restoran, kini terjadi persaingan antar pemilik bisnis restoran, hal inilah yang membuat pemilik restoran harus mempersiapkan diri dengan baik dan matang [1]. Dibandingkan dengan bisnis lain, makanan lebih menarik bagi mereka yang ingin memulai usaha mereka sendiri. Restoran merupakan salah satu usaha yang cukup banyak dilirik oleh para pengusaha. Hal tersebut dikarenakan beberapa alasan, antara lain hambatan untuk masuk ke makanan sangat http://ejournal.upbatam.ac.id/index.php/cbis rendah, permintaan dan kecintaan terhadap makanan sangat tinggi. Namun, meskipun bisnis ini sangat menarik, bisnis restoran bisa disebut salah satu yang paling menuntut dan sulit untuk dikelola. Kondisi tersebut terjadi karena berbagai restoran yang terus bermunculan / banyak kondisi buka tutup restoran yang sangat tinggi [2].

Pada bulan maret 2020, Organisasi Kesehatan Dunia atau WHO secara resmi mengumumkan bahwa status virus corona atau COVID19 sebagai pandemi. Status pandemi diumumkan setelah COVID19 menginfeksi 125.000 orang dan membunuh 45.000 lainnya di berbagai belahan dunia. COVID19, yang dimulai di Wuhan pada bulan desember 2019, telah menjalar dengan cepat ke seluruh dunia ke semua 
benua kecuali Antartika [3]. Fenomena virus Covid-19 yang muncul telah membawa perubahan penting di seluruh tatanan kehidupan, khususnya di sektor ekonomi. Sektor yang paling terdampak pada struktur perekonomian nasional ialah sektor hotel, restoran dan pariwisata [4]. Kondisi tersebut menambah tantangan baru para pemilik sektor bisnis seperti restoran untuk menciptakan strategi yang dapat menambah peningkatan terhadap penjualan dan pemasaran produk yang dipasarkan melalui penggunaan data penjualan produk. Data tersebut tidak hanya dapat digunakan sebagai dokumen perusahaan, tetapi juga dapat digunakan dan diubah menjadi informasi yang berguna untuk meningkatkan penjualan dan mempromosikan produk agar tetap bertahan dalam persaingan di tengah pandemi [5]. Data penjualan tersebut kemudian diolah menjadi model produk, yang biasanya dibeli oleh konsumen pada saat yang bersamaan, sehingga dapat dijadikan sebagai solusi nyata bagi para pengambil keputusan untuk menentukan strategi pemasaran dan memesan produk untuk meningkatkan pelayanan pelanggan.

PT John Tampi Group merupakan suatu perusahaan penyedia jasa pangan diberbagai bidang kuliner dan restoran di daerah Jakarta. Perusahaan ini merupakan perusahaan baru dalam persaingan bisnis dunia kuliner dengan dua cabang restoran di Jakarta. Hal tersebut dikarenakan perusahaan ini baru resmi dibuka pada bulan Februari 2020 oleh President Director PT John Tampi Group yang bernama John Henry Tampi. Menghadapi persaingan bisnis yang ketat dengan kompetitor lain di masa pandemi ini, perusahaan harus mengetahui pola pembelian dari pelanggan dengan menganalisis data transaksi penjualan [6]. Dalam mengambil suatu keputusan yang tepat untuk menentukan strategi penjualan dan menyusun target promosi yang tepat adalah mengetahui selera konsumen, dan mengetahui kebiasaan membeli konsumen mengenai produk (makanan dan minuman) apa yang sering dibeli, mengetahui pola pembelian produk oleh konsumen, yang dapat diamati melalui data transaksi pembelian. Data transaksi yang tersimpan memiliki informasi yang dapat diekstraksi untuk menghasilkan data atau pola data baru dengan menggunakan data mining. Misalnya informasi untuk mengetahui pola penjualan mengenai aturan asosiasi menu [1].
Market Basket Analysis merupakan teknik dalam data mining yang dapat mempelajari perilaku konsumen saat berbelanja. Analisis ini berusaha menemukan pola dari produk yang kerap dibeli bersamaan atau produk yang muncul bersamaan dalam data transaksi yang cenderung besar [6]. Market Basket Analysis dengan aturan asosiasi dapat membantu pemilik mengetahui kebutuhan pribadi konsumen dan jika ditangkap dapat digunakan untuk merancang strategi pemasaran yang tepat [7]. Algoritma Apriori merupakan algoritma yang paling sering digunakan dalam Market Basket Analysis. Namun selain algoritma Apriori terdapat algoritma lainnya yang sering diimplementasikan dalam penelitian, seperti algoritma FP-Growth dan Fuzzy C-Covering [8].

Beberapa penelitian telah dilakukan untuk menemukan aturan asosiasi dan pola perilaku pembelian konsumen. Pada tahun 2020, Kahar [8] melakukan perbandingan Market Basket Analysis mengenai data transaksi penjualan minimarket dengan algoritma Apriori, FP-Growth, dan Fuzzy $C$-Covering. Penelitian tersebut menunjukkan bahwa algoritma FP-Growth dapat memproses penggalian data dalam waktu yang paling singkat dan memberikan hasil yang paling akurat. Selanjutnya, Patron dan Gomez [9] pada tahun 2020 mengimplementasikan Market Basket Analysis pada data perbaikan mobil di AS. Hasil dari implementasi tersebut, mereka menemukan paket bundling yang tidak dieksploitasi yang dapat ditambahkan ke layanan pemeliharaan terjadwal dari kampanye pemasaran tradisional. Unvan [10] pada tahun 2020 menyatakan bahwa hasil perbandingan antara algoritma Apriori dan FP-Growth dalam rangka membuat Market Basket Analysis dengan menggunakan data supermarket memberikan ketentuan bahwa algoritma FP-Growth menghasilkan rule lebih unggul daripada algoritma Apriori.

Hal - hal di atas tersebut melatarbelakangi penelitian ini untuk mengimplementasikan algoritma FP-Growth dalam menentukan strategi PT John Tampi Group dengan menentukan pola asosiasi antar item berdasarkan pola pembellian konsumen pada data transaksi penjualan restoran.

\section{Kajian Literatur}

\subsection{Knowledge Discovery in Databases (KDD)}

Han dan Kamber [11] menggunakan istilah Knowledge Discovery in Database (KDD) dalam 
menjelaskan proses eksplorasi informasi yang tersembunyi dari kumpulan big data. Namun, meskipun konsep dari kedua istilah ini berbeda, namun kedua istilah tersebut saling terkait dan salah satu langkah dalam proses KDD adalah data mining. Langkah-langkah penting dalam proses KDD meliputi tahapan berikut [12]: 1) Data Selection, adalah tahapan dalam memilih data yang signifikan dan analisis data operasi dapat dilaksanakan. Data yang telah melalui tahap pemilihan selanjutnya akan disimpan dalam basis data yang berbeda; 2) Data Cleaning, tahapan dalam menghilangkan data imitasi, memeriksa ketidakkonsistenan data dan memperbaiki data yang salah (seperti kesalahan penulisan). Dalam banyak kasus, isi data tidak lengkap, seperti data hilang, data invalid, atau kesalahan dalam pengetikan. Selain itu, menghilangkan beberapa atribut data yang tidak ada hubungannya dengan asumsi penggalian data; 3) Data Integration, tahapan penambahan data yang tersedia ke data atau data terkait dalam proses yang disebut informasi, adalah penggabungan data dari basis data yang berbeda ke dalam basis data baru yang dibutuhkan KDD; 4) Data Transformation, proses konversi data menjadi data yang sesuai untuk tahapan selanjutnya, yaitu data mining dengan format tertentu. Misalnya, beberapa metode standar (seperti metode asosiasi dan klasifikasi) hanya dapat menerima entri data kategoris; 5) Data mining, proses menemukan pengetahuan berupa informasi atau pola yang berbeda dengan mengimplementasikan teknik, metode, atau algoritma tertentu. 6) Pattern Evaluation, identifikasi model yang sangat unik dalam penggalian data. Pada tahap ini, hasil dari teknik data mining dievaluasi dalam bentuk model unik dan model prediktif untuk menilai dugaan yang ada memang terpenuhi; 7) Knowledge Presentation, representasi pengetahuan menggambarkan sampel informasi yang diambil dari tahapan penggalian data. Visualisasi ini membantu mengomunikasikan hasil penambangan data dengan cara yang mudah dipahami.

\subsection{Data mining}

Data mining merupakan teknik dalam mengekstraksi dan menemukan wawasan dari sejumlah big data, basis data atau repositori database lainnya. Data mining memiliki tujuan utama untuk menemukan pengetahuan baru yang tersembunyi dalam database ini. Dalam proses ini, data mining meliputi data cleaning, data selection, data integration, data transformation, data mining, evaluation, dan knowledge presentation [11]. Data mining merupakan serangkaian proses yang dapat dibagi menjadi beberapa tahapan [13]. Langkah-langkah ini bersifat interaktif dan melibatkan pengguna secara langsung atau melalui basis pengetahuan. Tahapan yang dilakukan dalam proses data mining meliputi data selection, pre-processing, transformation, data mining dan interpretation/ evaluasi [14].

\subsection{Market Basket Analysis}

Analisis keranjang belanja adalah cara dalam menganalisis rutinitas belanja konsumen dengan menemukan hubungan antara item - item lainnya yang berbeda dalam keranjang belanja konsumen yang dibeli dalam transaksi tertentu. Tujuan dari analisis keranjang pasar adalah untuk menemukan produk yang dapat dibeli pada saat yang bersamaan [15]. Proses ini menganalisis kebiasaan pembelian konsumen dengan mencari hubungan antara berbagai item yang biasanya dibeli konsumen. Analisis ini akan menghasilkan rule yang sangat membantu para pelaku bisnis nantinya dalam melakukan perkembangan terhadap strategi pemasaran dan proses pengambilan keputusan dengan memperhatikan berbagai item yang kerap dibeli konsumen dalam waktu bersamaan [16]. Market Basket Analysis menunjukkan kombinasi produk apa yang paling sering terjadi bersamaan dalam pesanan. Hubungan ini dapat digunakan untuk meningkatkan profitabilitas melalui rekomendasi, promosi, penjualan silang atau bahkan penempatan item pada menu atau di toko. Diterapkan lebih dalam, analisis Keranjang Pasar memungkinkan perusahaan mengidentifikasi produk utama, produk yang membedakannya di pasar dan berpotensi merugikan bisnis jika tidak tersedia atau lebih mahal [10].

\subsection{Association Rule Minning}

Association Rule Mining ialah metode yang digunakan dalam menganalisis Keranjang Pasar. Hal ini diperlukan untuk membuat beberapa definisi sebelum melanjutkan ke pemeriksaan rinci dari analisis aturan asosiasi [10]. Analisis asosiasi atau penambangan aturan asosiasi adalah proses penambangan data dalam menemukan 
aturan asosiasi antara kombinasi item. Salah satu indikator yang menarik yang dapat digunakan dalam data mining adalah support. Ini merupakan indikator keunggulan suatu barang atau sekumpulan barang sepanjang suatu transaksi. Confidence adalah ukuran kondisional (dalam kondisi tertentu) dari hubungan antara dua faktor [17]. Nilai support untuk satu item diperoleh dengan persamaan 1, sedangkan untuk nilai support dengan dua item diperoleh dengan persamaan 2 [18].

Support $(\mathrm{A})=\frac{\text { jumlah transaksi A }}{\text { total transaksi }}$

Support $(\mathrm{A} \cap \mathrm{B})=\frac{\text { jumlah transaksi } A \text { dan } B}{\text { total transaksi }}$

Setelah nilai support ditemukan, maka langkah selanjutnya adalah mencari keberadaan aturan Confidence yang akan dihitung untuk menemukan aturan asosiatif $\mathrm{A} \rightarrow \mathrm{B}$ yang memenuhi persyaratan Confidence minimum [19]. Nilai Confidence diperoleh dari persamaan 3.

Confidence $(\mathrm{A} \cap \mathrm{B})=\frac{\text { jumlah transaksi } A \text { dan } B}{\text { jumlah transaksi } A}$

\subsection{Algoritma FP-Growth}

Algoritma FP-Growth merupakan sebuah algoritma dalam analisis keranjang belanja berlandaskan pohon yang diusulkan oleh Han pada tahun 2000. Han mengatakan algoritma ini sangat efisien karena membutuhkan data dua kali lebih banyak dari analisis dasar untuk menyelesaikan tugas pengumpulan informasi [18]. Algoritma FP-Growth adalah algoritma substitusi yang sangat kuat untuk menemukan dataset yang paling sering (frequent item set) dalam dataset yang besar. Algoritma FP-Growth adalah algoritma aturan asosiasi yang banyak digunakan dan merupakan perpanjangan dari algoritma Apriori [6]. Keuntungan terbesar yang ditemukan di FP-Growth adalah kenyataan bahwa algoritma ini hanya perlu membaca file dua kali, berbeda dengan Apriori yang membacanya sekali untuk setiap iterasi. Ini juga mengurangi biaya. Keuntungan besar lainnya adalah menghilangkan kebutuhan untuk menghitung pasangan yang akan dihitung, yang merupakan pemrosesan paling berat. Karena menggunakan FP-Tree. Ini membuatnya jauh lebih cepat daripada algoritma Apriori. Algoritma FP-Growth menyimpan memori dalam versi database yang ringkas [10].

\section{Metodologi}

Penelitian ini menggunakan data transaksi penjualan PT John Tampi Group dari pada tahun 2020. Metodologi yang diimplementasikan pada penelitian ini adalah KDD (Knowledge Discovery in Databases) dengan algoritma FP-Growth, dimana tahapannya meliputi data selection, data cleaning, data transformation, data mining, pattern evaluation dan knowledge information. Tahapan - tahapan dalam penelitian dapat dilihat pada gambar 2 .

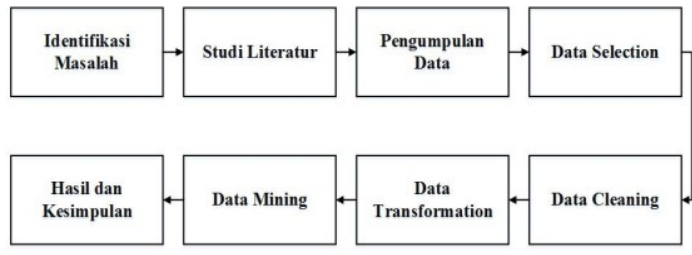

Gambar 2. Metodologi Penelitian

\section{Pembahasan}

\subsection{Pengumpulan Data}

Data yang digunakan dalam penelitian ini merupakan data primer yang diperoleh dari PT John Tampi Group. Data tersebut merupakan data transaksi penjualan PT John Tampi Group selama 7 bulan, yaitu dari bulan Februari 2020 sampai bulan september 2020 dengan jumlah atribut mencapai 17 atribut. Atribut - atribut tersebut dijelaskan pada tabel 1 berikut.

Tabel 1. Atribut - atribut data real transaksi

\begin{tabular}{lll}
\hline No & \multicolumn{1}{c}{ Atribut } & \multicolumn{1}{c}{ Keterangan } \\
\hline 1 & Outlet & Nama cabang Outlet \\
\hline 2 & Date & Tanggal Pembelian \\
\hline 3 & Time & Waktu Pembelian \\
\hline 4 & Gross Sales & Penjualan kotor \\
\hline 5 & Discounts & Diskon \\
\hline 6 & Refunds & Pengembalian dana \\
\hline 7 & Net Sales & Harga jual \\
\hline 8 & Gratuity & Persentase \\
\hline 9 & Tax & Pajak \\
\hline
\end{tabular}




\begin{tabular}{lll}
\hline 10 & $\begin{array}{l}\text { Total } \\
\text { Collected }\end{array}$ & Harga total \\
\hline 11 & $\begin{array}{l}\text { Other Note } \\
\text { (Optional) }\end{array}$ & Catatan Tambahan \\
\hline 12 & $\begin{array}{l}\text { Receipt } \\
\text { Number }\end{array}$ & No Pesanan \\
\hline 13 & Collected By & Penerima pesanan \\
\hline 14 & Served By & Pelayan \\
\hline 15 & Customer & Nama Customer \\
\hline 16 & Customer & No. Telp pelanggan \\
& Phone & Item makanan yang \\
\hline 17 & Items & dipesan \\
\hline
\end{tabular}

\subsection{Data Selection}

Data yang telah dikumpulkan selanjutnya diseleksi, karena tidak semua nilai dan atribut yang diperoleh sesuai dengan kebutuhan dari penelitian. Pada data real yang diperoleh dari hasil transaksi penjualan terdapat 17 atribut, yaitu Outlet, Date, Time, Gross Sales, Discounts, Refunds, Net Sales, Gratuity, Tax, Total Collected, Other Note, Receipt, Number Collected By, Served By, Customer, Customer Phone dan Items. Atribut yang digunakan dalam penelitian untuk menganalisis keranjang belanja dengan proses data mining yaitu atribut items. Dalam atribut tersebut terdapat beberapa record yang dihapus dikarenakan terjadi refund dalam transaksi, sehingga record yang digunakan dalam penelitian ini terdiri dari 3722 record yang terdiri dari berbagai macam item yang dibeli oleh konsumen.

Tabel 2. Atribut items

\begin{tabular}{|c|c|}
\hline No & Items \\
\hline 1 & $\begin{array}{l}\text { Chicken Chicken, Salted Egg Salted } \\
\text { Egg, Beef Beef,Szechuan Szechuan, } \\
\text { Mineral water }\end{array}$ \\
\hline 2 & $\begin{array}{l}\text { Noodle, Egg, Beef Beef, Salted Egg } \\
\text { Salted Egg, Fried Rice Fried Rice, } \\
\text { Egg, Chicken Chicken, Szechuan } \\
\text { Szechuan }\end{array}$ \\
\hline 3 & $\begin{array}{l}\text { Steamed Rice, Egg, Beef Beef, } \\
\text { Sambal Matah Sambal Matah }\end{array}$ \\
\hline
\end{tabular}

Fried Rice Fried Rice, Egg, Chicken Chicken, Sambal Matah Sambal

4 Matah, Fried Rice Fried Rice, Egg, Chicken Chicken, Black Pepper Black Pepper

5 Noodle, Egg, Chicken Chicken,
Black Pepper, Black Pepper

\begin{tabular}{ll}
\hline 6 & $\begin{array}{l}\text { Egg x 2, Steamed Rice x 2, Beef Beef } \\
\text { x 2, Butter Butter, Mineral water, } \\
\text { sambal Matah Sambal Matah }\end{array}$ \\
\hline 7 & $\begin{array}{l}\text { Steamed Rice x 2, Egg x 2, Beef Beef } \\
\text { x 2, Black Pepper, Black Pepper x 2, } \\
\text { Mineral water }\end{array}$ \\
\hline 8 & $\begin{array}{l}\text { Fried Rice Fried Rice, Egg, Chicken } \\
\text { Chicken, Salted Egg Salted Egg, } \\
\text { Coca Cola }\end{array}$ \\
\hline 9 & $\begin{array}{l}\text { Steamed Rice, Egg, Chicken } \\
\text { Chicken, Black Pepper Black Pepper, } \\
\text { Coca Cola }\end{array}$ \\
\hline $10 \quad \begin{array}{l}\text { Noodle, Egg, Chicken Chicken, } \\
\text { Extra Egg, Butter Butter }\end{array}$ \\
\hline
\end{tabular}

\begin{tabular}{ll}
\hline$\ldots$ & \multicolumn{1}{c}{$\ldots$} \\
\hline$\ldots$ & \multicolumn{1}{c}{$\ldots$} \\
\hline 3716 & $\begin{array}{l}\text { Noodle, Shrimp Shrimp, Dori Extra } \\
\text { Dori, Sambal Matah, Mineral water }\end{array}$ \\
\hline 3717 & Noodle \\
\hline 3718 & Egg Egg, Noodle \\
\hline 3719 & $\begin{array}{l}\text { Noodle, Egg Egg, Sambal Matah, } \\
\text { Milk Tea, Dori Dori }\end{array}$ \\
\hline 3720 & $\begin{array}{l}\text { Noodle, Beef Beef, Sambal Matah, } \\
\text { Coca Cola }\end{array}$ \\
\hline 3721 & $\begin{array}{l}\text { Egg Egg, Noodle, Chicken Chicken, } \\
\text { Black Paper }\end{array}$ \\
\hline 3722 & $\begin{array}{l}\text { Noodle, Chicken Chicken, Salted } \\
\text { Rgg, Coca Cola }\end{array}$ \\
\hline & Langkah analisis data dengan
\end{tabular}
mengimplementasikan algoritma FP-Growth dimulai dengan pemilihan dan pencarian data semua jenis produk yang akan dianalisis. Tabel 2 di atas merupakan hasil dari seleksi data penjualan PT John Tampi Group yang akan dijadikan sampel dalam penelitian. 


\subsection{Data Cleaning}

Pada tahap ini, data yang telah melalui tahap seleksi selanjutnya dilakukan pembersihan dan persiapan data untuk menghilangkan missing value, inkonsisten data, dan duplikasi pada data dalam data yang telah diperoleh.

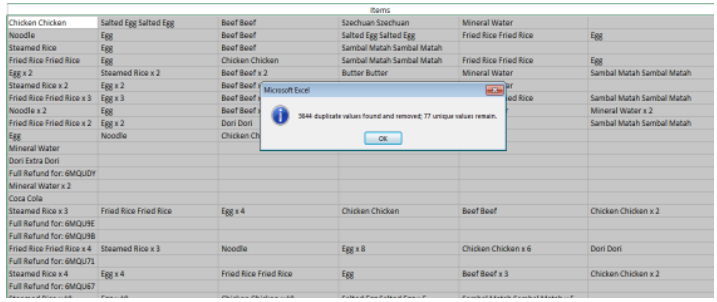

Gambar 2. Data Cleaning

Berdasarkan gambar 2 diatas, dapat dilihat bahwa masih terdapat noise atau inkonsisten data sehingga perlu dilakukan pembersihan pada data transaksi tersebut. Setelah data dibersihkan, data tersebut dapat diolah untuk tahapan selanjutnya.

\subsection{Data Transformation}

Tahap selanjutnya adalah melakukan transformasi data. Tahap transformasi data dilakukan pada data embelian produk, dimana nilai 1 adalah produk yang dibeli oleh pelanggan dan nilai 0 adalah produk yang tidak dibeli oleh pelanggan dalam transaksinya. Perhitungan transformasi data didukung oleh aplikasi Microsoft Excel. Hasil dari proses transformasi dapat dilihat pada gambar 2 .

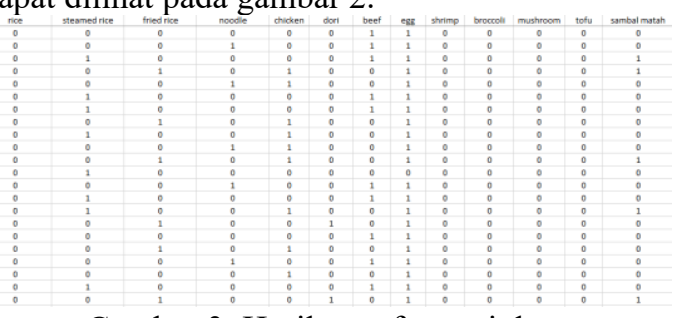

Gambar 3. Hasil transformasi data

\subsection{Data mining}

Tahap data mining dilakukan dengan memilih metode algoritma untuk menemukan pola atau informasi dalam data transaksi PT John Tampi Group. Dataset yang disediakan akan dimuat kedalam Rapidminer terlebih dahulu, dan langkah selanjutnya memilih algoritma mana yang akan digunakan. Kemudian untuk mengetahui frekuensi dari atribut yang sering terjadi, hitung frekuensi atribut dari hasil penambahan setiap atribut dari setiap transaksi yang terjadi. Jika penghitungan dilakukan secara manual dengan bantuan aplikasi Microsoft Excel dan Rapidminer, data yang dihasilkan akan terlihat seperti tabel 3 .

Tabel 3. Frekuensi dari setiap atribut dengan menggunakan Microsoft Excel

\begin{tabular}{lll}
\hline No & Produk & Frequent \\
\hline 1 & Rice & 1504 \\
\hline 2 & Steamed Rice & 258 \\
\hline 3 & Fried Rice & 400 \\
\hline 4 & Noodle & 906 \\
\hline 5 & Chicken & 969 \\
\hline 6 & Dori & 473 \\
\hline 7 & Beef & 996 \\
\hline 9 & Egg & 2859 \\
\hline 10 & Shrimp & 194 \\
\hline 11 & Broccoli & 8 \\
\hline 12 & Tofushroom & 2 \\
\hline 13 & Sambal matah & 31 \\
\hline 14 & Black pepper & 596 \\
\hline 15 & Salted & 616 \\
\hline 16 & Szechuan & 399 \\
\hline 17 & Choy sum & 71 \\
\hline 18 & Mineral water & 152 \\
\hline 19 & Coca cola & 35 \\
\hline & & \\
\hline
\end{tabular}

Tabel 4. Frekuensi dari setiap atribut dengan menggunakan tools Rapidminer

\begin{tabular}{lll}
\hline No & Nama & Values \\
\hline 1 & Rice & $0(2217), 1(1504)$ \\
\hline 2 & steamed Rice & $0(3463), 1(258)$ \\
\hline 3 & fried Rice & $0(3321), 1(400)$ \\
\hline 4 & Noodle & $0(2815), 1(906)$ \\
\hline 5 & Chicken & $0(2752), 1(969)$ \\
\hline 6 & dori & $0(3248), 1(473)$ \\
\hline 7 & Beef & $0(2725), 1(996)$ \\
\hline 8 & Egg & $1(2859), 0(862)$ \\
\hline 10 & shrimp & $0(3527), 1(194)$ \\
\hline 11 & broccoli & $0(3713), 1(8)$ \\
\hline 12 & tofushroom & $0(3719), 1(2)$ \\
\hline & & $0(3690), 1(31)$ \\
\hline
\end{tabular}




\begin{tabular}{lll}
\hline 13 & sambal matah & $0(3125), 1(596)$ \\
\hline 14 & black pepper & $0(3297), 1(424)$ \\
\hline 15 & salted & $0(3105), 1(616)$ \\
\hline 16 & Szechuan & $0(3322), 1(399)$ \\
\hline 17 & choy sum & $0(3650), 1(71)$ \\
\hline 18 & Mineral water & $0(3569), 1(152)$ \\
\hline 19 & coca cola & $0(3686), 1(35)$ \\
\hline
\end{tabular}

Berdasarkan kedua tabel tersebut, dapat dilihat bahwa frekuensi atribut terbesar terdapat pada atribut Rice dengan total frekuensi 1504 terjual. Setelah diperoleh frekuensi itemset terbesar, tahap selanjutnya yaitu menampilkan hasil dari proses support dari itemset dengan menggunakan persamaan 1 dan 2. Adapun hasil yang diperoleh bantuan aplikasi Rapidminer dalam mencari nilai support dapat dilihat pada tabel 5 .

Tabel 5. Nilai support itemset

\begin{tabular}{llll}
\hline No & Support & Item 1 & Item 2 \\
\hline 1 & 0.707 & Mineral water & Beef \\
\hline 2 & 0.390 & Mineral water & Rice \\
\hline 3 & 0.246 & Mineral water & Chicken \\
\hline 4 & 0.232 & Mineral water & Noodle \\
\hline 5 & 0.230 & Mineral water & Egg \\
\hline 6 & 0.673 & Szechuan & Beef \\
\hline 7 & 0.355 & Szechuan & Rice \\
\hline 8 & 0.234 & Szechuan & Chicken \\
\hline 9 & 0.202 & Szechuan & Noodle \\
\hline 10 & 0.230 & Szechuan & Egg \\
\hline 11 & 0.277 & Beef & Rice \\
\hline 12 & 0.260 & Beef & Chicken \\
\hline 13 & 0.228 & Beef & Egg \\
\hline
\end{tabular}
itemset, maka tahap selanjutnya adalah menentukan nilai Confidence dari itemset. Berdasarkan nilai support dan Confidence yang telah diperoleh, penelitian ini akan menetapkan nilai support $95 \%$ dengan nilai Confidence $80 \%$. Berikut hasil pengujian dengan nilai support $95 \%$ dan nilai Confidence $80 \%$ dengan bantuan aplikasi Rapidminer dapat dilihat pada tabel 6 .
Tabel 6. Hasil dari Association Rule

\begin{tabular}{llll}
\hline Premises & $\begin{array}{l}\text { Concluss } \\
\text { ion }\end{array}$ & Support & Confidence \\
\hline Rice & Szechuan & 0,355 & 0,879 \\
\hline $\begin{array}{l}\text { Mineral } \\
\text { water }\end{array}$ & Szechuan & 0,858 & 0,894 \\
\hline Chicken & Szechuan & 0,234 & 0,898 \\
\hline Beef & Szechuan & 0,673 & 0,919 \\
\hline Chicken & $\begin{array}{l}\text { Mineral } \\
\text { water }\end{array}$ & 0,246 & 0,946 \\
\hline Noodle & $\begin{array}{l}\text { Mineral } \\
\text { water }\end{array}$ & 0,232 & 0,954 \\
\hline Szechuan & $\begin{array}{l}\text { Mineral } \\
\text { water }\end{array}$ & 0,858 & 0,961 \\
\hline Rice & $\begin{array}{l}\text { Mineral } \\
\text { water }\end{array}$ & 0,390 & 0,965 \\
\hline Beef & $\begin{array}{l}\text { Mineral } \\
\text { water }\end{array}$ & 0,707 & 0,966 \\
\hline Egg & Beef & 0,228 & 0,985 \\
\hline Egg & $\begin{array}{l}\text { Mineral } \\
\text { water }\end{array}$ & 0,230 & 0,992 \\
\hline Egg & Szechuan & 0,230 & 0,992 \\
\hline Chicken & Beef & 0,260 & 1 \\
\hline Berdar & & \\
\hline
\end{tabular}

Berdasarkan hasil pengujian yang dilakukan pada data transaksi PT John Tampi Group dengan bantuan tools Rapidminer dapat dinyatakan bahwa algoritma FP-Growth dapat digunakan untuk menentukan strategi promosi restoran. Hasil dari keseluruhan penelitian ini diperoleh 13 relasi atau keterkaitan antar item yang dipesan oleh costumer dalam transaksi. Dibawah ini merupakan hasil rule-rule yang diperoleh berdasarkan nilai support dan Confidence dari pengujian dengan menggunakan tools Rapidminer yang dapat digunakan sebagai strategi promosi restoran.

Tabel 7. Association Rule berdasarkan nilai Confidence

\begin{tabular}{llll}
\hline No & Association Rules & \\
\hline 1 & {$[$ Rice] --> } & [Szechuan] & (Confidence: \\
& $0.879)$ & & \\
\hline 2 & {$[$ Mineral water] --> } & [Szechuan] \\
& (Confidence: 0.894$)$ & \\
\hline 3 & [Chicken] --> [Szechuan] (Confidence: \\
& $0.898)$ \\
\hline
\end{tabular}




\begin{tabular}{|c|c|}
\hline 4 & $\begin{array}{l}\text { [Beef] --> [Szechuan] (Confidence: } \\
0.919)\end{array}$ \\
\hline 5 & $\begin{array}{l}\text { [Chicken] --> [Mineral water] } \\
\text { (Confidence: } 0.946)\end{array}$ \\
\hline 6 & $\begin{array}{l}{[\text { Noodle }] \quad-->\quad[\text { Mineral }} \\
\text { (Confidence: } 0.954)\end{array}$ \\
\hline 7 & $\begin{array}{l}\text { [Szechuan] --> [Mineral water }] \\
\text { (Confidence: } 0.961)\end{array}$ \\
\hline 8 & $\begin{array}{l}\text { [Rice] --> [Mineral water] (Confidence: } \\
0.965)\end{array}$ \\
\hline 9 & $\begin{array}{l}\text { [Beef] --> [Mineral water] (Confidence: } \\
0.966)\end{array}$ \\
\hline 10 & [Egg] --> [Beef] (Confidence: 0.985) \\
\hline 11 & $\begin{array}{l}\text { [Egg] --> [Mineral water] (Confidence: } \\
0.992)\end{array}$ \\
\hline 12 & $\begin{array}{llll}\text { [Egg] } & --> & \text { [Szechuan }] \text { (Confidence: } \\
0.992) & & & \\
\end{array}$ \\
\hline 13 & $\begin{array}{llll}\text { [Chicken] } & --> & \text { [Beef }] \text { (Confider } \\
1.000) & & & \end{array}$ \\
\hline
\end{tabular}

Dilihat dari tabel 7 diatas, nilai
Confidence tertinggi yang dihasilkan dari association rules dengan menggunakan algoritma FP-Growth pada data transaksi restoran mencapai $100 \%$ dengan aturan setiap pembelian chicken maka dapat dipastikan akan membeli beef yang kemudian data ini dapat dijadikan sebagai strategi promosi seperti potongan harga, beli satu produk mendapat satu produk atau bahan promosi lainnya.

\section{Kesimpulan}

Dari hasil pengolahan data data transaksi penjualan PT John Tampi Group dari bulan februari 2020 sampai bulan september 2020 yaitu sebanyak 3.722 transaksi, dapat diperoleh bahwa Confidence tertinggi dari hasil pengujian mencapai 1 atau sekitar 100\% dengan aturan setiap pembelian chicken maka dapat dipastikan akan membeli beef yang kemudian data ini dapat dijadikan promosi seperti potongan harga, beli satu poduk mendapatkan satu produk atau bahan promosi lainnya. Hasil dari pengolahan data tersebut juga dapat memberikan manfaat pada konsumen maupun produsen. Keuntungan bagi konsumen yaitu konsumen dapat mengetahui produk apa saja yang menjadi rekomendasi dari perusahaan tersebut dan juga mendapat kesempatan untuk memperoleh promosi produk seperti potongan harga, beli satu poduk mendapatkan satu produk atau bahan promosi lainnya. Keuntungan bagi produsen yaitu produsen dapat mengetahui produk apa saja yang menjadi produk unggulan yang dapat dijadikan bahan promosi, selain itu produsen dapat pula menyusun produk-produk apa saja yang akan diletakkan ditempat yang sama sehingga memudahkan karyawan dalam menyiapkan produk-produk tersebut. Penelitian ini hanya dilakukan dengan menggunakan algoritma $F P$ Growth untuk menentukan keterkaitan antar item menu makanan yang dipesan oleh costumer Diharapkan untuk melakukan penelitian lebih lanjut dengan penggabungan algoritma lain untuk mendapatkan hasil yang lebih baik.

\section{Daftar Pustaka}

[1] Y. Kurnia, Y. Isharianto, Y. C. Giap dan A. Hermawan, "Study of application of data mining Market Basket Analysis for knowing sales pattern (association of items) at the $\mathrm{O}$ ! Fish restaurant using apriori algorithm," Journal of Physics: Conference Series, pp. $1-6,2019$.

[2] W. R. Septiyani dan M. E. S. Rejeki, "Studi Kasus Kualitatif Keberhasilan Restoran Non Waralaba di Yogyakarta," Jurnal Inovasi Penelitian, vol. 1, no. 7, pp. 1475 1487, 2020.

[3] Liliyana, "Implementasi Bauran Promosi Pada Usaha Kuliner Restoran Bumbu Desa Ciledug di Masa Pandemi Covid-19," AKRAB JUARA, vol. 5, no. 4, pp. 228 - 243, 2020.

[4] A. A. I. Fisabil dan D. T. Salsabila, "Analisis Rasio Kebangkrutan Perusahaan pada Masa Pandemi Covid-19," Jurnal Akutansi, vol. 13, no. 1, pp. 99-108, 2021.

[5] M. Badrul, "Penentuan Strategi Marketing Penjualan Produk dengan Algoritma Apriori," KNiST, pp. 50-56, 2017.

[6] N. D. Andriai, T. W. Utami dan R. Wasodo, "Implementasi Algoritma FP-Growth dalam Market Basket Analysis untuk 
Menganalisis Pola Belanja Konsumen Pada Data Transaksi Penjualan," Jurnal Ilmiah, 2019.

[7] K. K. Halim dan S. Halim, "Business Intelligence for Designing Restaurant Marketing Strategy : A Case Study," ELSEVIER, vol. 161, pp. 615-622, 2019.

[8] R. N. Kahar, "Perbandingan Analisa Market Basket Analysis Terhadap Data Penjualan Minimarket dengan Algoritma Apriori, FPGrowth dan Fuzzy C-Covering," Prosiding Seminar Nasional Informatika dan Sistem Informasi, vol. 3, no. 3, pp. 250-268, 2021.

[9] H. Patron dan L. Gomez, "A Market Basket Analysis of the US auto-repair Industry," Journal of Business Analytics, vol. 3, no. 2, pp. 79-92, 2020.

[10] Y. A. Ünvan, "Market Basket Analysis with association rules," Communications in Statistics - Theory and Methods, pp. 1 - 14, 2020.

[11] J. Han dan M. Kamber, Data mining : Concept and Techniques, Third. Edition, Waltham: Morgan Kauffman Publisher, 2012.

[12] A. M. Siregar dan A. Puspabhuana, DATA MINING: Pengolahan Data Menjadi Informasi dengan Rapid Miner, CV Kekata Group, 2017.

[13] E. Elisa, "Analisa dan Penerapan Algoritma C4.5 Dalam Data mining Untuk Mengidentifikasi Faktor-Faktor Penyebab Kecelakaan Kerja Kontruksi PT.Arupadhatu Adisesanti," JOIN, pp. 3641, 2017.
[14] M. P. Tana, F. Marisa dan I. D. Wijaya, "Penerapan Metode Data mining Market Basket Analysis Terhadap Data Penjualan Produk Pada Oase Menggunakan Algoritma Apriori," JIMP, vol. 3, no. 2, pp. 17-22, 2018.

[15] F. Fatihatul, A. Setiawan dan R. Rosadi, Asosiasi Data mining Menggunakan Algoritma FP-Growth Untuk Market Basket Analysis, Jatinangor: Universitas Padjajaran, 2011.

[16] K. Fatmawati dan A. P. Windarto, "Data mining : Penrapan Rapidminer Dengan KMeans Cluster Pada Daerah Terjangkit Demam Berdarah Dangue (DBD)," Journal of Computer Enginering, System and Science, vol. 3, no. 2, pp. 173-178, 2018.

[17] W. P. Nurmayanti, H. M. Sastriana dan A. Rahim, "Market Basket Analysis with Apriori Algorithm and Frequent Pattern Growth (FP-Growth) on Outdoor Product Sales Data," International Journal of Educational Research \& Social Sciences, pp. 133-139, 2021.

[18] A. N. S. Putro dan R. I. Gunawan, "Implementasi Algoritma FP-Growth Untuk Strategi Pemasaran Ritel Hidroponik (Studi Kasus : PT. HAB)," Jurnal Buana Informatika, vol. 10, no. 1, pp. 12-18, 2019.

[19] A. Abdullah, "Rekomendasi Paket Produk Guna Meningkatkan Penjualan dengan Metode FP-Growth," Khazanah Informatika Jurnal Ilmu Komputer dan Informatika, vol. 4, no. 1, pp. 21-26, 2018. 